\title{
Effect of covid-19 on financial markets: Evidence from Pakistan, India and Italy
}

\author{
Muhammad Sohail Khalil \\ Assistant Professor at Institute of Management Sciences, Peshawar Pakistan \\ sohail.khalil@imsciences.edu.pk
}

\author{
Usman Ullah \\ Student at the Department of Accounting and Finance \\ Institute of Management Sciences, Peshawar Pakistan \\ usmanullahdirv@gmail.com
}

\begin{abstract}
The novel corona virus called as covid-19 spread worldwide affecting the health and economic status of countries all over the globe. The major aim of this study was to analyze the stock prices during the covid-19 pandemic. The sample of the study is taken from 15 May to 15 June 2020, stock prices as well as the covid-19 confirmed cases of three countries Pakistan, India and Italy. This study has both practical and theoretical implications. Investment behavior, efficient market hypothesis and the prediction of stock prices during the anticipated 2nd wave of covid-19 are some of the main points this study has covered. Further study is needed to examine pre, mid and post lockdown impact on stock prices. This study applied simple regression model to examine the impact of covid-19 on financial markets from 15 May to 15 June 2020 in Pakistan, India \& Italy. The study findings were intriguing. The study findings indicate that there is positive significant relation among these variables (Positive cases and stock prices) on that period of time (15 May to 15 June 2020 in Pakistan, India \& Italy). This research suggests that covid-19 confirmed positive cases had significant impact on financial markets during 15 May to 15 June 2020 on these three stock indices of Pakistan, India and Italy (KSE-100, SENSEX \& FTSE Italia).
\end{abstract}

Key Words: Covid-19, Stock indices, Stock prices, Corona positive confirm cases, Efficient market hypothesis

\section{Introduction}

The outbreak came as a fully unprecedented event with highly contagious emergence in the state of Wuhan, China in late December 2019. It was announced by WHO to be a deadly disease with no prior vaccine in the market. The WHO announced it on 11th of March as global pandemic as it spread across the globe. The cities were locked down, travelling activities suspended; people were quarantined as quickly as possible to ensure the social distancing the only solution of that time (Ashraf, 2020). These actions created highly uncertain situation for the global economy as well as for financial markets. According to Ashraf (2020) stock markets provide much useful information in sharp evolving and complex environments. As the metropolitan cities of many countries were locked due to the virus and government officials announced the health emergency 
the situation got worst. We are examining the stock market prices with cases and deaths due to covid-19. Covid-19 has massively impacted all financial markets universally by causing the share prices to plummet continuously and significantly (Sansa, 2020). According to daily FT (2020, page 1) both stock exchanges Dow Jones and S\&P companies taken into consideration show 20\% drop in the share prices. Another example is from Japan where Nikkei index for the Tokyo Stock Exchange experienced downfall of share prices. Daily FT also reported that the Nikkei index dropped significantly within few days. As a complete lockdown was announced worldwide in those areas where most positive cases appeared, the stock exchanges were also closed with limited trading activities, resulting in sharp decrease in stock prices. Ramelli, Wagner and Zhang et al (2020) argued that if strict actions of government reduce the intensity of local outbreaks, then it will weaken the negative market reaction to the growth in covid-19 confirm cases. Corbet et al (2020) examined the impact of word corona on stock returns and according to the results it showed that companies had strong hourly volatility when the corona was announced for the first time. Covid-19 greatly affected the stock markets and businesses all over the world. It created uncertainty in business community and stopped them from investing. As a result, various countries observed difficulties in terms of their economic activities. Within 100 days, the financial markets declined by 30 percent. The situation has worsened as the global spread has gone beyond geographical and continental boundaries, with even safer commodities like gold returns turning negative as COVID-19 spreads to the US but still found to be least the volatile. Chinese stock markets recovered as the covid-19 was ravaging through USA, owing to the timely actions taken by the Chinese authorities.

\section{Research Objective}

The objective of the study is to examine how corona virus affected the stock exchanges in Pakistan, India and Italy in the duration of most positive confirmed cases in Asia and Europe from 15 May to 15 June 2020. The covid-19 was way more shocking than the financial crisis back in 2008. It has significant impact on financial markets globally and has not been studied yet with regard to the financial world. International magazines and experts have predicted the 2 nd wave of Covid-19 as well. These downward trends were observed in every covid-19 affected stock exchange.

\section{Literature Review}

This study derives motivation from the current COVID-19 global pandemic, to measure the relativity of the news of health trends to the predictability of shares market returns. The study explains top 20 worst hit countries by COVID-19. The research was based on panel data structure forecasting approach in a short-time span since the pandemic emergence. Categories 20 most affected countries in term of death and cases reported, data structure of the market share returns in a series, due to insufficient observation problem analysis of worst hit countries was encircled. The study conclude that the effect of market shares return and health news has a significant negative effect, revealing that market stock returns decrease as more information is gathered on health problems since pandemic spreading (Salisua \& Vo, 2020).

Research on COVID-19 financial impacts is still in its earliest stages with most investigations zeroing in on the effect of COVID-19 on the US and other nations significantly influenced by the episode regarding number of fatalities. Alfaro et al (2020) noted that qualities in the US stock market dropped because of the pandemic. Yilmazkuday (2020) studied the effect of number of COVID-19 US affirmed cases and deaths on the list of the S\&P 500 market list and reports that having a $1 \%$ expansion in the combined day by day affirmed COVID-19 US cases is related with 
a markdown of $0.01 \%$ in the S\&P 500 file in the following day, and $0.03 \%$ decrease in the following month. Mamaysky (2020) additionally certifies this lead-slack connection between news delivered and the financial markets. In any case, likewise investigates how number of affirmed Corona virus cases and deaths influence the US stock market and contends that there is certainly not a critical impact on US stock market returns yet there is a surprising effect on the unpredictability of the US stock market in any event, when cases were accounted for in nations other than the US (Ali A, Alam B \& Rizvi, 2020).

Italy has been the major center of Covid-19 in Europe which recorded far more deaths than china and definite relative economic and financial loss. Italy stopped two way flight activities with china with immediate effect. Italian goods are no longer proceeding to china which is worth $\$ 16$ millions. As Italy recorded most deaths in Europe the other European countries closed the borders and that affected Italy investments. In addition to that the North side of Italy is hit hard by Covid19 which has the highest per capita GDP of $\$ 38000$ and employment rate of $67 \%$ as compared to the southern side with $\$ 28000$ GDP and 59\% employment rate. It indicates that northern side of the Italy is more affected economically due to COVID-19 as compare to other regions (subacchi, 2020). In Feb, 2020 the bond market, commodity market, and equity market have seek safety for a while. There was a record low level of 10 years Treasury bond of United States of America which came down to $0.499 \%$ in Feb, 2020.

The results of those findings contribute to the examination of economic impacts of the pandemic by providing experimental evidence that COVID-19 has bidirectional spill-over effect on the Chinese economy and the current seven other countries that are affected by the outburst. (He et all, 2020). Yilmazkuday suggested that covid-19 fatality rate more than $1 \%$ will cause about $0.02 \%$ cumulative reduction in Standard \& Poor-500 in one day. And the same rate will go like 0.06 in week and 0.08 percent after the month. Alfaro et al (2020) examined that shares revenues respond to daily unanticipated fluctuations in predicted cases based on standard model of disease. Their results indicated decline in stock market volatility as the graph of the pandemic become less certain. In other countries Machmuddah et al (2020) studied that back in 2003 stock market reacted fast and strong in countries which suffered from severe acute respiratory syndrome. Where some of the researchers argued that stock price reactions was strong in countries having high debt to GDP ratio. Ramelli and Wagner (2020) is of the view that covid-19 health crisis reverse into financial crisis. They have studied the SOPs for the covid-19 and its impact on stock market indices. The results of the studies showed that months of lockdowns, stopping of international flights and money travel across the countries greatly influenced the level of economic activities. On the other hand the restrictions on movement and higher fiscal policy spending positively affected economic situations.

The People's Bank of China also injected liquidity of amounting 240 billion dollars in to economy to overcome the drawbacks of viruses. Additionally, the European Central Bank also worked for countering the COVID-19. Since the situation worsens day by day, for which they may take more serious actions which they feel necessary in the situation. Although, capital market and banking sector is also working to stabilize the situation and they are ready to take every step which is necessary for controlling the situation of COVID-19 (Baret et all, 2020). Due to this pandemic, the stock markets witnessed a major decrease in its stock prices. It almost destroyed the business all over the world. The aim of this paper is to study and analyze the impact of COVID19 on major financial markets in terms of their decline and volatility in stock prices. We will also see its impact on commodity markets and will study the response of investors to 
these unpleasant events. Almost all financial assets show negative returns and higher volatility due to COVID19. But the US government bonds showed no volatility (Ali A, Alam B \& Rizvi, 2020). Crude oil has the highest volatility but we cannot say that this volatility is solely due to COVID-19. Volatility in crude oil is also due to the disputes in oil producing nations. European countries observed higher negative returns as compare to other markets (Ali A, Alam B \& Rizvi, 2020).

\section{Data and Methodology}

This current study is undertaken to examine the impact of covid-19 on the financial markets from 15 may to 15 June 2020 in Pakistan, India and Italy. Italy was selected for this study because it is the worst hit country in Europe. Similarly India was selected for the same reason as it is the worst hit country in Asia. Pakistan being the native country of the authors as well as a neighbor of India and still doing considerably better was selected for the aforementioned reasons. The duration from 15 May 2020 to 15 June 2020 was selected because in that time period the pandemic was as its peak with a high ratio of positive cases and high mortality rate. The simple regression model is used to examine the impact of covid-19 on these three financial indices. Time series data from WHO data sets and the relevant website of Pakistani Government on corona is collected. In this study we used KSE-100 index for Pakistan, Mumbai stock exchange for India and FTSE Italia All share index for Italy. On this whole study the covid-19 positive confirmed cases assumed to be independent variable and the stock returns of the each country as dependent variable. In this study we used the double Log and semi log linear models to examine the affect of covid-19 on financial markets from 15 may to 15 June 2020. This research or study design is descriptive analysis using the quantitative method with the help of Microsoft excel 2007. The data is collected through secondary source. The Pakistan covid-19 confirmed and cumulative cases data was taken from the WHO website. The India and Italy confirmed covid-19 cases data is also taken from WHO data source website. The stock indices daily stock prices data is collected from the investing.com internet site. This study has been carried out under the following equation to examine the impact of covid-19 on the financial markets of Pakistan, India and Italy.

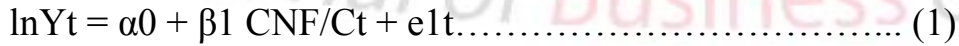

In the above equation that we have taken the natural log of dependent variable which is stock prices. CNF/C shows the covid-19 confirmed positive cases. The alpha shows constant and beta is the coefficient of parameter.

For checking the correlation we took the natural log of dependent variable which is stock prices of the three countries.

$\operatorname{lnKSEt}=\alpha 0+\beta 1 \mathrm{CNF} / \mathrm{Ct}+\mathrm{e} 1 \mathrm{t} \ldots \ldots \ldots \ldots \ldots \ldots \ldots \ldots \ldots$ (2) $\operatorname{lnKSE}$ shows the natural $\log$ of Pakistan stock exchange prices.

Same was the equation for Italy and India stock indices as well.

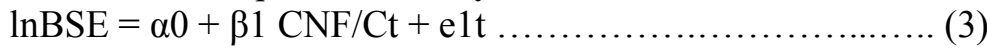

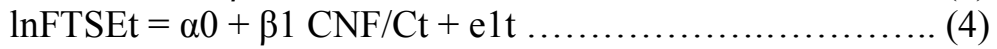

The lnBSE and lnFTSE shows the natural log of Mumbai stock exchange and Italy all shares indices. Through this equation we have measured the correlation of the two variables. 
Table 1: Covid-19 daily cases of Pakistan, India \& Italy from 15 May to 15 June

\begin{tabular}{|c|c|c|c|}
\hline Date Reported & Pakistan covid-19 Cases & India Covid-19 Cases & Italy Covid-19 Cases \\
\hline $5 / 14 / 2020$ & 1452 & 3722 & 888 \\
\hline $5 / 15 / 2020$ & 1430 & 3967 & 992 \\
\hline $5 / 16 / 2020$ & 1581 & 3970 & 789 \\
\hline $5 / 17 / 2020$ & 1352 & 4987 & 875 \\
\hline $5 / 18 / 2020$ & 1974 & 5242 & 675 \\
\hline $5 / 19 / 2020$ & 1841 & 4970 & 451 \\
\hline $5 / 20 / 2020$ & 1932 & 5611 & 813 \\
\hline $5 / 21 / 2020$ & 2193 & 5609 & 665 \\
\hline $5 / 22 / 2020$ & 2603 & 6088 & 642 \\
\hline $5 / 23 / 2020$ & 1743 & 6654 & 652 \\
\hline $5 / 24 / 2020$ & 2164 & 6767 & 669 \\
\hline $5 / 25 / 2020$ & 1748 & 6977 & 531 \\
\hline $5 / 26 / 2020$ & 1356 & 6535 & 300 \\
\hline $5 / 27 / 2020$ & 1446 & 6387 & 397 \\
\hline $5 / 28 / 2020$ & 2076 & 6566 & 584 \\
\hline $5 / 29 / 2020$ & 2801 & 7466 & 593 \\
\hline $5 / 30 / 2020$ & 2429 & 7964 & 516 \\
\hline $5 / 31 / 2020$ & 3039 & 8380 & 416 \\
\hline $6 / 01 / 2020$ & $2964 \leq 0$ & 8392 & 355 \\
\hline $6 / 02 / 2020$ & $3938 \sim 7$ & 8171 & 178 \\
\hline $6 / 03 / 2020$ & 406501001 & $8909 \circlearrowleft$ & 318 \\
\hline $6 / 04 / 2020$ & 4801 & 9304 & 321 \\
\hline $6 / 05 / 2020$ & 3985 & 9851 & 177 \\
\hline $6 / 06 / 2020$ & 4734 & 9887 & 518 \\
\hline $6 / 07 / 2020$ & 4960 & 9971 & 270 \\
\hline $6 / 08 / 2020$ & 4728 & 9983 & 197 \\
\hline $6 / 09 / 2020$ & 4646 & 9987 & 280 \\
\hline $6 / 10 / 2020$ & 5385 & 9985 & 283 \\
\hline $6 / 11 / 2020$ & 5834 & 9996 & 202 \\
\hline $6 / 12 / 2020$ & 5985 & 10956 & 379 \\
\hline $6 / 13 / 2020$ & 6884 & 11458 & 163 \\
\hline $6 / 14 / 2020$ & 6825 & 11929 & 346 \\
\hline $6 / 15 / 2020$ & 5248 & 11502 & 338 \\
\hline
\end{tabular}


The table 1 shows the daily cases of covid-19 of Pakistan, India and Italy from 15 May to 15 June 2020. This data is collected from the WHO website and organized in the Excel 2007.

\section{Graph 1: Pakistan cumulative cases of covid-19}

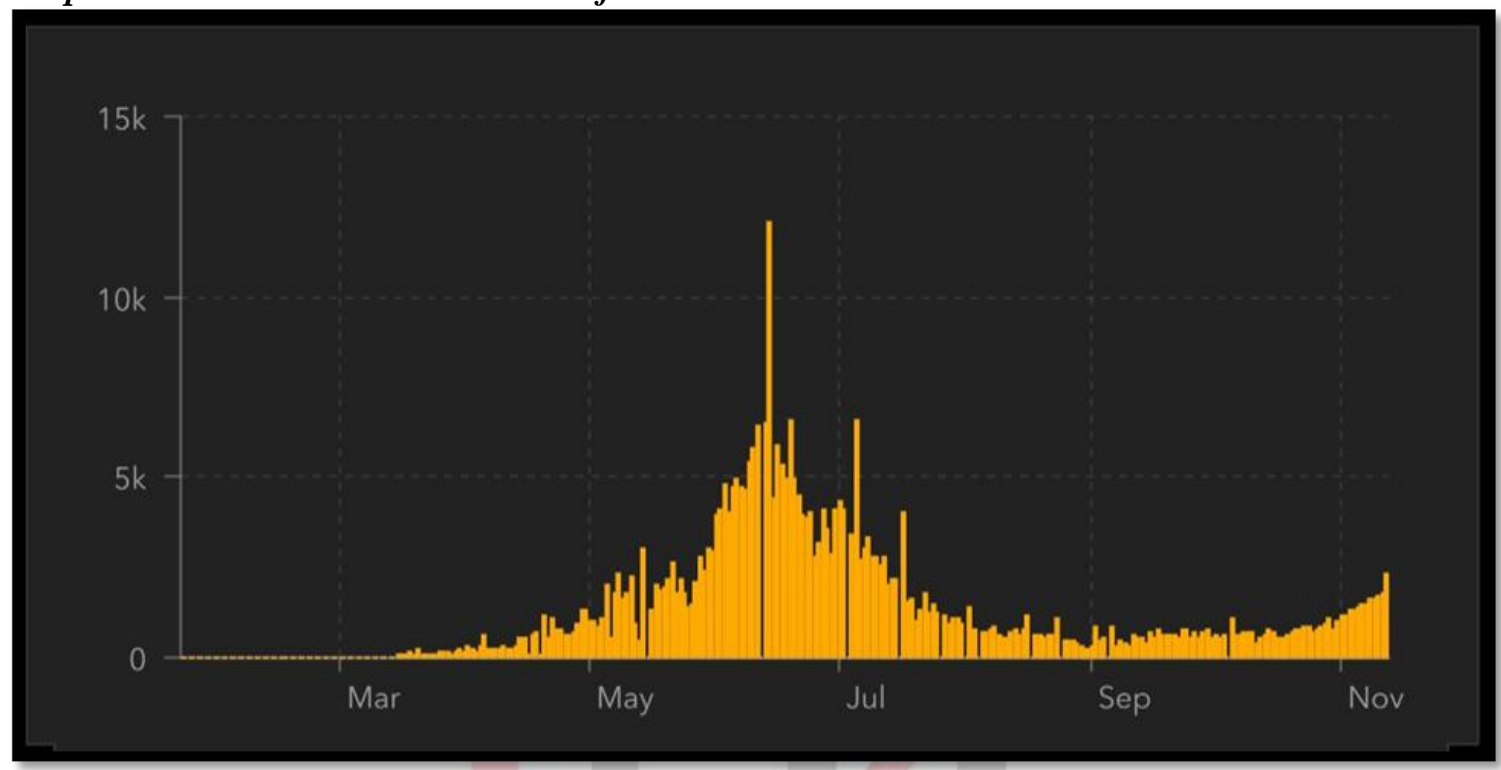

The graphs 1 show the cumulative and daily cases of covid-19 of Pakistan starting from March 2020 to November 2020. This figure is taken from the John Hopkins University corona resource center USA. As it indicates that after the month May the graph hit the highest ratio ever in the whole duration of the first wave from March to august 2020. Same is the case for India as well which was affected between May and July 2020. From the Indian state health department on May 22, 2020 the Hindu news figures were as 6,510 confirmed cases with a total of 69,140 and 51,666 recoveries.

\section{Graph 2: India cumulative cases of covid-19}

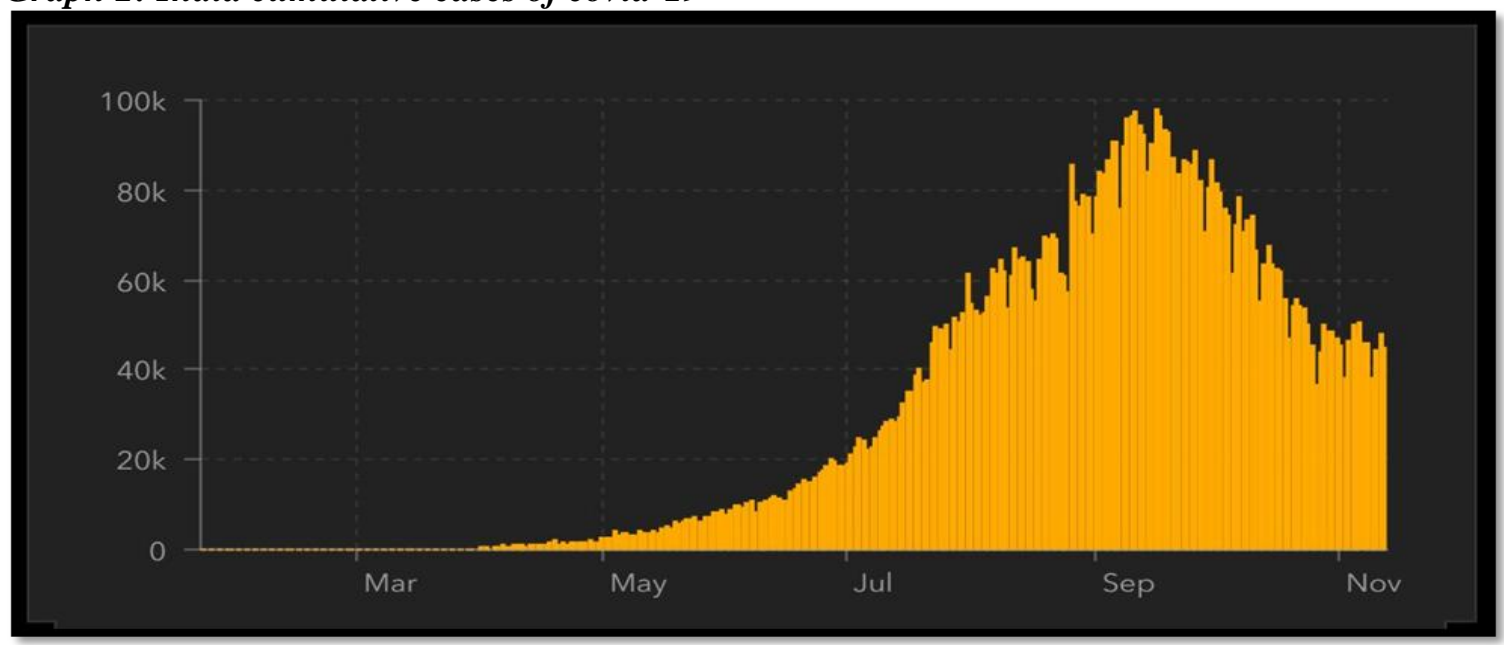


Graph 3: Italy cumulative cases of covid-19

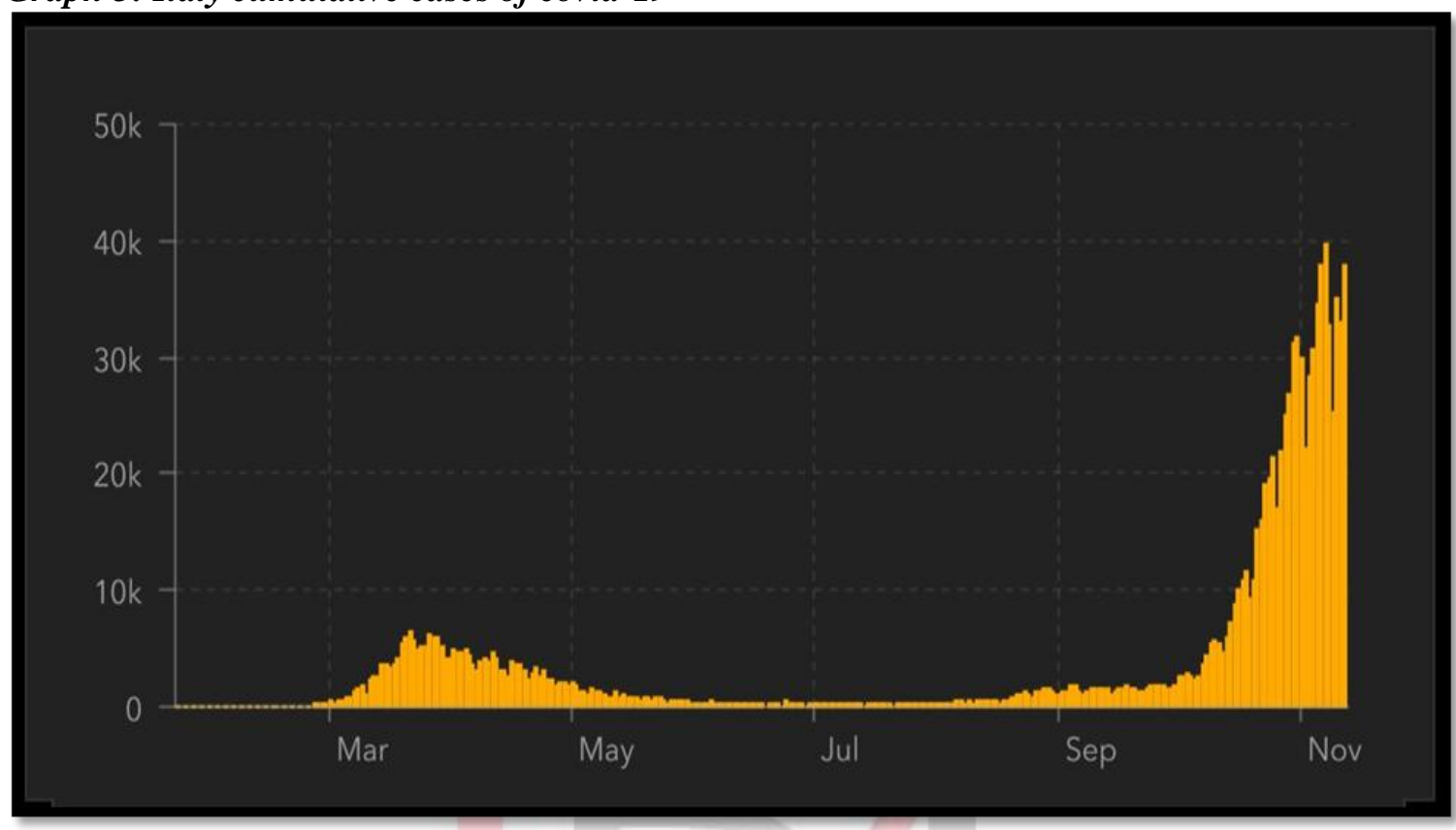

In the duration of May to June 2020 the covid-19 cases of Italy as compared to Pakistan and India show slight decrease.

\section{Empirical Results and Discussion}

The study descriptive summery and regression showed that there is significant impact of covid-19 on financial markets of Pakistan, India and Italy during that time period of 31 days. The main focus of the study was to examine the affect of covid-19 on financial markets during 15 May and 15 June 2020 . This study was especially conducted for three countries which had most peak cases during that time period in the first wave of covid-19.

\section{Table 2: Descriptive Summery}

\begin{tabular}{|llll|}
\hline Mean & Pakistan & INDIA & ITALY \\
& 10.4548 & 10.4589 & 9.9056 \\
\hline SD & 0.026 & 0.04015 & 0.0607 \\
\hline S.E & & 0.0709 & 0.0107 \\
\hline Min & 0.00472 & 10.309 & 9.8176 \\
\hline Max & 10.40 & 12.644 & 10.001 \\
\hline
\end{tabular}

In the descriptive summery of the data set the standard error for the KSE-100 is 0.0472 , for India it is 0.07 and in the case of Italy it is 0.01 . The standard error is not high in terms of the sample size. In the case of KSE 100 the standard deviation is 0.026. The data is not deviated that much because the sample size is not large but in that duration the stock prices moved with high 
volatility. In the case of Mumbai stock exchange prices the standard deviation is 0.04 . And for Italia ALL share index the deviation of the data from the mean is 0.06 .

Table 3: Regression statistics for KSE-100 index with covid-19 confirmed cases

\begin{tabular}{|l|c|}
\hline Multiple R/ Correlation Coefficient & 0.63697631 \\
\hline R Square & 0.4057388 \\
\hline Adjusted R Square & 0.38593011 \\
\hline Standard Error & 0.047588817 \\
\hline P Value & $1.97232956728062 \mathrm{E}-60$ \\
\hline T Statistics & -1.86071 \\
\hline No of Observations & 32 \\
\hline
\end{tabular}

Table 3 indicates the $\log , \log$ and semi log regression results of KSE 100 index which is Karachi stock exchange of Pakistan with the covid-19 confirmed positive cases from 15 May to 15 June 2020. The dependent variable is KSE-100 index stock prices and independent variable is covid-19 confirmed positive cases.

Table 4: Regression Test Results for Mumbai Stock Index (SENSEX) and Covid-19 Confirmed Cases

\begin{tabular}{|l|c|}
\hline Multiple R/ Correlation Coefficient & 0.847414093 \\
\hline R Square & 0.718110646 \\
\hline Adjusted R square / & 0.708714334 \\
\hline Standard Error & 0.0256215 \\
\hline P Value & $5.73457 \mathrm{E}-05$ \\
\hline T Statistics & -6.742124 \\
\hline No of Observations & 32 \\
\hline
\end{tabular}

The correlation coefficient for the Mumbai stock exchange is 0.84 as approaching to 1 showing the strong correlation. In the case of FTSE Italia All share index the correlation coefficient is 0.63 which comparatively show good sign as approaches to 1 . The value of R square is 0.040 for KSE100 and covid-19 confirmed positive cases between $15^{\text {th }}$ may to $15^{\text {th }}$ June. The value of $\mathrm{R}$ square for the Mumbai stock index is 0.708714 and FTSE all share index is 0.405738 in the period of 15 May to 15 June 2020. 
Table 5: Regression Test Result of FTSE Italia All Share Index with Covid-19 Confirmed Positive Cases

\begin{tabular}{|l|c|}
\hline Multiple R/ Correlation Coefficient & 0.63697631 \\
\hline R Square & 0.4057388 \\
\hline Adjusted R Square & 0.385930113 \\
\hline Standard Error & 0.047588817 \\
\hline P Value & $1.97233 \mathrm{E}-60$ \\
\hline T Statistics & 4.525799 \\
\hline No of Observations & 32 \\
\hline
\end{tabular}

The overall regression findings show that as there is significant positive impact of covid-19 on financial markets of Pakistan, India and Italy (KSE 100, SENSEX \& FTSE Italia) from 15 May to 15 June 2020.

\section{Limitations of the Study}

These findings are for very limited time period and consider only the two Asian and one European country. The further researchers have to consider longer time period and other variables as well to examine the stock prices more elaborately. As the covid-19 $2^{\text {nd }}$ wave is approaching I suggest comparing before and after lockdown prices and returns of the stock indices to be studied in future.

\section{Conclusion of the Study}

This pandemic has great impact on businesses therefore big organizations should respond accurately to the situation. Research and findings provide strategic pathways in organizations expansion and exponential growth. This study finding suggests that there is significant positive impact of covid-19 confirmed cases on financial markets of Pakistan, India and Italy stock price indices in the duration of that one month (15 may to 15 June). This study has been carried out to examine the impact of covid-19 on the financial markets of Pakistan, India and Italy from the May 15 to June 15 2020. The findings and results of the study reveal that covid-19 has significant positive impact on stock prices of KSE-100, SENSEX \& FTSE Italia ALL share index. This study will provide literature for the further studies and will create new knowledge regarding the impact of covid-19 on financial markets. This study will facilitate investors and researchers in decision making in future. It will be very useful on applied side of finance for the managers and investors of different institutions. 


\section{References}

Ashraf, B.N. (2020). Stock markets' reaction to COVID-19: cases or fatalities?. Res. Int. Bus. Finance 54, 101249.

Baig, A., Butt, H.A., Haroon, O. \& Rizvi, S.A.R. (2020). Deaths, panic, lockdowns and US equity markets: the case of COVID-19 Pandemic, Working Paper, 21 April, doi: $10.2139 /$ ssrn. 3584947.

Baret, S., Celner, A., O'Reilly, M. \& Shilling, M. (2020). COVID - 19 Potential Implications For The Banking And Capital Markets Sector. Maintaining Business And Operational Resilience. Deloitte Insights.

Daily FT. (2020). COVID - 19: The Economic Impact Simplified. October, 2020.

Economy. (2020). Financial Markets Rattled by the Multiple Effects Of COVID - 19.

He, Q., Liu, J., Wang, S. \& Yu, J. (2020). The impact of COVID-19 on stock markets. Economic and Political Studies, Vol. 8 (3), pp. 1-14, doi: 10.1080/20954816.2020.1757570.

Investing.com (2020). International indices. at: https://www.investing.com/indices/ftse-italia-allshare (accessed October 2020).

John Hopkins university corona resource center (2020). global covid-19 data at: https://coronavirus.jhu.edu/data accessed on November 2020

Machmuddah .Z, Utomo St. D, Suhartono.E, Ali.S \& ALI.G.W (2020). Stock Market Reaction to COVID-19: Evidence in Customer Goods Sector with the Implication for Open Innovation" J. Open Innov. Technol. Mark. Complex. 6, 99 http://dx.doi.org/10.3390/joitmc6040099

Mamaysky, H. (2020). Financial markets and news about the coronavirus. Available at: https://papers.ssrn.com/sol3/papers.cfm?abstract_id1/43565597.

Ramelli, S., \& Wagner, A.F. (2020). Feverish Stock Price Reactions to COVID-19. Rev. Corp. Financ. Stud. cfaa012. Available online: https://papers.ssrn.com/sol3/papers.cfm?abstract_id=3550274 (accessed on October 2020).

Sansa, N.A. (2020). The impact of the COVID-19 on the financial markets: Evidence from China and USA. Electron. Res. J. Soc. Sci. Humanit. 2. Available online: https://papers.ssrn.com/sol3/papers.cfm?abstract_id=3567901 (accessed on October 2020).

Subacchi, P. (2020). This is how the Coronavirus is affecting Italy's economy. World Economic $\begin{array}{lllll}\text { Forum. } & \text { Retrieved } & \text { April } & 20, & 2020\end{array}$ https://www.weforum.org/agenda/2020/03/italycoronavirus-econoic-slow-down-virusoutbreak

Sansa, N. A. (2020). The Correlation between COVID-19 Confirmed and Recovered Cases in China: Simple Regression Linear Model Evidence. Electronic Research Journal of Social Sciences and Humanities 2 (I), pp. 121-129

WHO (2020). Coronavirus (COVID-19). available at: https://who.sprinklr.com/ (accessed October 2020).

Yilmazkuday, H. (2020). COVID-19 Effects on the s\&p 500 Index. 2020. Available online: https://papers.ssrn.com/ sol3/papers.cfm?abstract_id=3555433 (accessed on October 2020). 